\title{
Plasma Tissue Factor in Coronary Artery Disease: Further Step to the Understanding of the Basic Mechanisms of Coronary Artery Thrombosis
}

\author{
J. VOJÁČEK ${ }^{1}$, J. DUŠEK ${ }^{1}$, J. BIS ${ }^{1}$, J. ŠŤÁSEK ${ }^{1}$, M. BLAŽEK ${ }^{2}$ \\ ${ }^{1}$ First Department of Medicine and ${ }^{2}$ Second Department of Medicine, Charles University in Prague, \\ Faculty of Medicine in Hradec Králové and University Hospital Hradec Králové, Czech Republic
}

Received August 17, 2006

Accepted January 2, 2007

On-line available January 2, 2007

\section{Summary}

Tissue factor is a cell surface protein that is expressed constitutively by monocytes, macrophages and fibroblasts, but also by some other cells in response to a variety of stimuli. The main function of the tissue factor is to form a complex with factor VII/VIIa that converts factors IX and $X$ to their active forms. Tissue factor is also involved in the pathophysiology of systemic inflammatory disorders, coagulopathies, atherosclerotic disease, tumor angiogenesis and metastasis. Increased tissue factor expression either locally in the coronary plaques or systematically on circulating blood elements of patients with acute coronary syndromes may be responsible for increased thrombin generation, thus leading to platelet activation and fibrin formation. Tissue factor therefore plays a pivotal role in the initiation of thrombotic complications in patients with coronary artery disease.
\end{abstract}

\section{Key words}

Coronary artery disease $\bullet$ Coronary thrombosis $\bullet$ Tissue factor

\section{Corresponding author}

Jan Vojacek, Department Medicine I, University Hospital, 50005 Hradec Kralove, Czech Republic. Fax: ++ 420495832006 , E-mail: vojacjan@fnhk.cz

\section{Tissue factor and coagulation}

Tissue factor is a cell surface protein that is expressed constitutively by monocytes, macrophages and fibroblasts (Mackman et al. 1991, Taubman et al. 1993, Kamimura et al. 2004, Penn et al. 1999). Some authors also describe tissue factor expression by cardiomyocytes
(Mumford and McVey 2004). Tissue factor forms a complex with factor VII/VIIa that converts factors IX and $\mathrm{X}$ to their active forms. The blood borne tissue factor has been discovered recently. However, TF may also be expressed in some other cell types in response to a variety of stimuli. The initiation phase of thrombus generation begins when the disruption of vessel wall or atherosclerotic plaques exposes tissue factor to circulating factor VII, thus leading to the activation of both the intrinsic and extrinsic blood coagulation cascades (Rosenberg and Aird 1999). The tissue factor also induces cell signaling by stimulating G-proteincoupled protease activated receptors (PARs). Signaling pathways initiated by both TF/VIIa complex protease activation of PARs and phosphorylation of the tissue factor cytoplasmic domain appear to regulate different cellular functions (Rao and Pendurthi 2005). In normal arteries, tissue factor expression is limited to the adventitia except for sporadic expression in the media (Wilcoxon et al. 1989). A small quantity of circulating tissue factor is present in both the whole blood and serum of healthy individuals (Giesen and Nemerson 2000). The tissue factor is also involved in the pathophysiology of systemic inflammatory disorders, coagulopathies, atherosclerotic disease, chronic renal failure (Zemanová et al. 2003), tumor angiogenesis and metastasis (Price et al. 2004). There is a significant positive correlation between tissue factor level and serum creatinine, glycemia, LDL cholesterol, number of cigarettes smoked per day (Sambola et al. 2003) and an inverse correlation 
between tissue factor level and serum insulin (Zemanová et al. 2003).

\section{Tissue factor in coronary artery disease}

Inappropriate expression of the tissue factor may result in thrombosis contributing to acute clinical consequences of coronary artery disease. Experimental data show that atheromatous plaques contain a high concentration of tissue factor relative to surrounding tissue (Marmur et al. 1996). Abundant tissue factor is also found in atheromatous lesions within foamy macrophages in macrovascular disease in humans such as aortic aneurysms and carotid arteries (Wilcoxon et al. 1989). Ruptures of atheromatous plaques (usually multiple) expose tissue factor to circulating factor VII causing the initiation of a clot formation and may consequently lead to an abrupt vessel closure and myocardial infarction. This can be demonstrated by the examination of tissue samples obtained from patients with acute coronary syndromes, where higher levels of tissue factor are present in these lesions. In this way, the tissue factor may play not only a role in the development of acute coronary syndromes but also in the progression of coronary artery disease (Annex et al. 1995, Ardissino et al. 1997, Mann and Davies 1999, Westmuckett et al. 2000) via the tissue factor-dependent intramural fibrin deposition after plaque rupture and subsequent progression of the atherosclerotic lesion (Westmuckett et al. 2000). Modified ELISA (Westmuckett et al. 2000) and a rabbit polyclonal antibody against the solubilized tissue factor activity (Thiruvikraman et al. 1996) were used for in situ localization of the tissue factor in human atherosclerotic plaques. Quantitation of tissue factor antigen was done to test the hypothesis that thrombin generation takes place directly in the atherosclerotic lesion (Thiruvikraman et al. 1996). This findings support the possible role of the tissue factor-dependent coagulation pathway in the intramural fibrin deposition and the progression of the atherosclerotic lesions.

Detached endothelial cells as well as microparticles from endothelial cell monolayers express tissue factor activity and this activity is markedly inhibited by microparticle-associated tissue factor pathway inhibitor (Kushak et al. 2005).

Apart from the role, which the tissue factor has in the acute coronary syndromes, tissue factor expression has a potential role in vascular remodeling after coronary angioplasty. Cell culture studies have demonstrated that the TF/VIIa complex is critical for smooth muscle cell migration (Siegbahn et al. 2000). Furthermore, TF/VIIamediated smooth muscle cell migration can be inhibited by the overexpression of the tissue factor pathway inhibitor. The links between lipoproteins and tissue factor expression, as well as tissue factor and vascular remodeling (Singh et al. 2001) suggest a potential mechanism for the surprisingly early benefits of highdose statin therapy in patients with acute coronary syndrome. Alternatively, statin therapy could be beneficial by decreasing CRP levels in these patients, because C-reactive protein has been shown to induce tissue factor expression in monocytes (Cermak et al. 1993).

Heparin treatment is associated with a decrease in tissue factor plasma levels and monocyte procoagulant activity (Gori et al. 1999) as well as with increased plasma level of the tissue factor pathway inhibitor.

Arnaud et al. (2000) investigated whether individual differences in tissue factor gene expression could predispose subjects to thrombosis. They sequenced the 5' domain of the gene and found six different polymorphisms. Genotyping of patients with myocardial infarction in a case-control study involving 2354 subjects showed no association between the polymorphisms and nonfatal coronary thrombosis (Arnaud et al. 2000).

Many studies demonstrated elevated tissue factor plasma levels in patients with myocardial infarction (Saigo et al. 2001), stable angina (Kim et al. 2000), unstable angina and an increased risk for unfavorable outcomes in patients with unstable angina and raised tissue factor levels. Other authors found only a nonsignificant trend to raised plasma levels of tissue factor in patients with acute myocardial infarction and unstable angina pectoris as compared to patients with stable coronary artery disease and normal subjects (Malý et al. 2003). Tissue factor could be useful for the evaluation of the effect of cardiovascular risk intervention, but results in this field are still controversial (Lim et al. 2004). Can tissue factor also be used as a prognostic marker in patients with cardiovascular disease? Seljeflot et al. (2003) followed patients after myocardial infarction for 4 years. Patients, who had suffered an endpoint event (reinfarction or stroke), had significantly higher tissue factor levels as compared to those who did not. Other authors (Sambola et al. 2003, Lim et al. 2004) reported higher plasma levels of tissue factor in patients with diabetes than in control subjects. They suggest that higher levels of tissue factor may be the mechanism responsible 
for the increased thrombotic complications associated with the presence of other cardiovascular risk factors. No significant differences were found between diabetics and non-diabetics in patients with chronic renal failure (Zemanová et al. 2003).

\section{Diagnostic tests for plasma tissue factor}

The plasma level of tissue factor may be determined by means of the commercially available Tissue Factor ELISA Kit. The kit employs a murine antihuman tissue factor monoclonal antibody for antigen capture. Plasma samples are incubated in microtest wells precoated with capture antibody. Once captured, the tissue factor is detected using a biotinylated antibody fragment that specifically recognizes the bound tissue factor. The subsequent binding of horseradish peroxidase conjugated streptavidin completes the formation of the antibody-enzyme detection complex. Quantitative data are obtained by measuring the solution absorbance at $450 \mathrm{~nm}$ and relating it to the standard curve. The detection limit of this assay is about $10 \mathrm{pg} / \mathrm{ml}$.

Tissue factor may circulate in the blood incorporated in pro-coagulant microparticles shedded as membrane vesicles (Mallat et al. 1999). Moreover, a form of human tissue factor generated by alternative splicing has been identified (Bogdanov et al. 2003). Alternatively spliced human tissue factor is soluble, circulates in the blood, exhibits pro-coagulant activity when exposed to phospholipids, and is incorporated into thrombi and thus may contribute to thrombus growth (Bogdanov et al. 2003). Plasma tissue factor activity not associated with cells or microparticles has also been studied. Tissue factor-dependent generation of factor $\mathrm{Xa}$ on cryosections was used to assess the functional activity of the tissue factor (Thiruvikraman et al. 1996).

To employ tissue factor as a useful marker of atherothrombosis, a very sensitive diagnostic test for its detection and quantitation is needed. High-affinity antibodies are employed in the improved version of ELISA diagnostic tests for tissue factor plasma level assessment (Chen et al. 2005). The new assays provide higher sensitivity with much lower detection limit than currently available diagnostic sets. Data obtained by these assays also show markedly reduced individual variation. Higher sensitivity in tissue factor detection is of critical value especially in the group of patients with normal or slightly elevated tissue factor levels and opens a new field for research. It is also very important to detect accurately also low levels of tissue factor in order to use tissue factor as a potentially useful tool for risk stratification in patients with cardiovascular disease.

However, the question how to interpret an elevated tissue factor levels still remains unanswered. Additional investigations will be necessary for better acceptance of the tissue factor as an independent biomarker for cardiovascular risk that we can incorporate into decision-making algorithms. We should not ignore the limited specificity with elevated tissue factor levels in a variety of different clinical situations. Larger scale clinical studies should confirm the independent significance of the tissue factor.

\section{Conflict of Interest}

There is no conflict of interest.

\section{Acknowledgements}

This paper was supported by the Research Grant IGA NR/8131-3 and NR/9176-3.

\section{References}

ANNEX BH, DENNING SM, CHANNON KM: Differential expression of tissue factor protein in directional atherectomy specimens from patients with stable and unstable coronary syndromes. Circulation 91: 28392843, 1995.

ARDISSINO D, MERLINI PA, ARIENS R, COPPOLA R, BRAMUCCI E, MANNUCCI PM: Tissue factor antigen and activity in human coronary atherosclerotic plaques. Lancet 348: 769-771, 1997.

ARNAUD E, BARBALAT V, NICAUD V, CAMBIEN F, EVANS A, MORRISON C, ARVEILER D, LUC G, RUIDAVETS JB, EMMERICH J, FIESSINGER JN, AIACH M: Polymorphisms in the 5' regulatory region of the tissue factor gene and the risk of myocardial infarction and venous thromboembolism: the ECTIM and PATHROS studies: Etude Cas-Temoins de l'Infarctus du Myocarde: Paris thrombosis case-control study. Arterioscler Thromb Vasc Biol 20: 892-898, 2000. 
BOGDANOV VY, BALASUBRAMANIAN V, HATHCOCK J, VELE O, LIEB M, NEMERSON Y: Alternatively spliced human tissue factor: a circulating, soluble, thrombogenic protein. Nat Med 9: 458 - 462, 2003.

CERMAK J, KEY NS, BACH RR, BALLA J, JACOB HS, VERCELLOTTI GM: C-reactive protein induces human peripheral blood monocytes to synthesize tissue factor. Blood 82: 513-520, 1993.

CHEN C, YANG Q, PATEL S, LEI Y, MCALEER L, SINGLETON LP, SOLTIS D, WANG B: Characterization of human tissue factor (TF)-specific monoclonal antibodies prepared using a rapid immunization protocol. Hybridoma (Larchmt.) 24: 78-85, 2005.

GIESEN PL, NEMERSON Y: Tissue factor on the loose. Semin Thromb Hemost 26: 379-384, 2000.

GORI AM, PEPE G, ATTANASIO M, FALCIANI M, ABBATE R, PRISCO D, FEDI S, GIUSTI B, BRUNELLI T, COMEGLIO P, GENSINI GF, NERI SERNERI GG: Tissue factor reduction and tissue factor pathway inhibitor release after heparin administration. Thromb Haemost 81: 589-593, 1999.

KAMIMURA M, BEA F, AKIZAWA T, KATUS A, KREUZER J, VIEDT C: Platelet-derived growth factor induces tissue factor expression in vascular smooth muscle cells via activation of Egr-1. Hypertension 44: 944-51, 2004.

KIM HK, SONG KS, PARK YS, YUN YS, SHIM W:. Changes of plasma tissue factor and tissue factor pathway inhibitor antigen levels and induction of tissue factor expression on the monocytes in coronary artery disease. Cardiology 93: 31-36, 2000.

KUSHAK RI, NESTORIDI E, LAMBERT J, SELIG MK, INGELFINGER JR, GRABOWSKI EF: Detached endothelial cells and microparticles as sources of tissue factor activity. Thromb Res 116: 409-419, 2005.

LIM HS, BLANN AD, LIP GYH: Soluble CD40 ligand, soluble P-selektin, interleukin-6, and tissue factor in diabetes mellitus. Circulation 109: 2524-2528, 2004.

MACKMAN N, BRAND K, EDGINGTON TS: Lipopolysacharide-mediated transcriptional activation of the human tissue factor gene in THP-1 monocytic cells requires both activator protein 1 and nuclear factor kappa B binding sites. $J$ Exp Med 174: 1517-1526, 1991.

MALLAT Z, HUGEL B, OHAN J, LESECHE G, FREYSSINET JM, TEDGUI A: Shed membrane microparticles with procoagulant potential in human atherosclerotic plaques: a role for apoptosis in plaque thrombogenicity. Circulation 99: 348-53, 1999.

MALÝ M, VOJÁČEK J, HRABOŠ V, KVASNIČKA J, SALAJ P, DURDIL V: Tissue factor, tissue factor pathway inhibitor and cytoadhesive molecules in patients with an acute coronary syndrome. Physiol Res 52: 719-728, 2003.

MANN J, DAVIES MJ: Mechanisms of progression in native coronary artery disease: role of healed plaque disruption. Heart 82: 265-268, 1999.

MARMUR JD, THIRUVIKRAMAN SV, FYFE BS: Identification of active tissue factor in human atherosclerotic plaques in human coronary atheroma. Circulation 94: 1226-1232, 1996.

MUMFORD AD, MCVEY JH. Tissue factor in the myocardium evidence of roles in haemostasis and inflammation. Dis Markers 20: 353-8, 2004.

PENN MS, PATEL CV, CUI MZ, DICORLETO PE, CHISOLM GM: LDL increase inactive tissue factor on vascular smooth muscle cells surfaces: hydrogen peroxide activates cell surface tissue factor. Circulation 99: 1753-59, 1999.

PRICE GC, THOMPSON, KAM PCA: Tissue factor and tissue factor pathway inhibitor. Anaesthesia 59: 483-492, 2004.

RAO LV, PENDURTHI UR: Tissue factor-factor VIIa signaling. Arterioscler Thromb Vasc Biol 25: 47-56, 2005.

ROSENBERG RD, AIRD WC. Vascular-bed-specific hemostasis and hypercoagulable states. $N$ Engl J Med 340: 15551564, 1999.

SAIGO M, ABE S, OGAWA M, YAMASHITA T, BIRO S, MINAGOE S, MARUYAMA I, TEI C: Imbalance of plasminogen activator inhibitor-I/tissue plasminogen activator and tissue factor/tissue factor pathway inhibitor in young Japanese men with myocardial infarction. Thromb Haemost 86: 1197-1203, 2001. 
SAMBOLA A, OSENDE J, HATHCOCK J, DEGEN M, NEMERSON Y, FUSTER V, CRANDALL J, BADIMON JJ: Role of risk factors in the modulation of tissue factor activity and blood thrombogenicity. Circulation 107: 973-977, 2003.

SELJEFLOT I, HURLEN M, ARNESEN H: Levels of soluble tissue factor related to future clinical events in patients with myocardial infarction. Thromb Haemost Suppl 1: P0495, 2003 (abstract).

SIEGBAHN A, JOHNELL M, RORSMAN C, EZBAN M, HELDIN CH, RONNSTRAND L: Binding of factor VIIa to tissue factor on human fibroblasts leads to activation of phospholipase $\mathrm{C}$ and enhanced PDGF-BB-stimulated chemotaxis. Blood 96: 3452-3458, 2000.

SINGH R, PAN S, MUESKE CS, WITT T, KLEPPE LS, PETERSON TE, SLOBODOVA A, CHANG JY, CAPLICE NM, SIMARY RD: Role of tissue factor pathway in murine model of vascular remodeling. Circ Res 89: 71-76, 2001.

TAUBMAN MB, MARMUR JD, ROSENFIELD CL, GUHA A, NICHTBERGER S, NEMERSON Y: Agonistmediated tissue factor expression in vascular smooth muscle cells: role of calcium mobilization and protein kinase C activation. J Clin Invest 91: 547-552, 1993.

THIRUVIKRAMAN SV, GUHA A, ROBOZ J, TAUBMAN MB, NEMERSON Y, FALLON JT: In situ localization of tissue factor in human atherosclerotic plaques by binding of digoxigenin-labeled factors VIIa and X. Lab Invest 75: 451-61, 1996.

WESTMUCKETT AD, LUPU C, GOULDING DA, DAS S, KAKKAR VV, LUPU F: In situ analysis of tissue factordependent thrombin generation in human atherosclerotic vessels. Thromb Haemost. 84: 904-11, 2000.

WILCOXON JN, SMITH KM, SCHWARTZ SM, GORDON D: Localization of tissue factor in the normal vessel wall and the atherosclerotic plaque. Proc Natl Acad Sci USA 84: 2839-2843, 1989.

ZEMANOVÁ P, OPATRNÝ K, OPATRNÁ S, VÍT L, ŠEFRNA F, RACEK J: Tissue factor, its pathway inhibitor, and metabolic disturbances in long-term peritoneal dialysis. Kidney Blood Press Res 26: 368-375, 2003. 